\title{
THE SIGNIFICANCE OF THE SODIUM AND POTASSIUM CONTENT OF MUSCLE TISSUE AND THE RELATION OF THE AMOUNT OF EDEMA FLUID IN MUSCLE TO THE LEVEL OF SERUM PROTEIN IN EXPERIMENTAL NUTRITIONAL EDEMA
}

\author{
By WM. B. MCCLURE AND WINIFRED FRANZ HINMAN \\ (From the Otho S. A. Sprague Memorial Institute Laboratory of the Children's Memorial \\ Hospital, Chicago)
}

(Received for publication December 3, 1936)

In investigating the mechanism of edema formation, we have made a study of the relations of sodium and potassium to the water in muscles of animals suffering from nutritional edema, in order to learn whether these relations provide evidence as to the validity of the hypothesis that fluid retention associated with hypoproteinemia is simply an accumulation of an ultrafiltrate from the circulating plasma. These relations might also indicate whether sodium has any rôle in the production of edema other than that of being the chief base of plasma filtrate, this question having been often raised by the observed necessity of ingested sodium for the formation of experimental plasmapheresis edemas in dogs $(1,2,3)$, and for the occurrence of nutritional (4) and nephrotic (5) edemas in man. A nutritional edema in white rats resulting from a protein-poor carrot diet $(6,7)$ and shown to be accompanied by low serum proteins $(8,9)$ was decided upon as a practical experimental setting for the problem.

\section{DIETS}

Kohman (6) demonstrated that the edema in her animals had not resulted from the lack of any of the vitamins then known, and was presumably the result of protein deficiency in the diet. Vitamin $G$ had not then been identified and may not have been supplied in sufficient quantity to Kohman's rats by the wheat-germ extract. We have sought to learn whether such deficiency could have had any effect on the course of the - edema. Accordingly, a group of five animals was placed on the Kohman wet diet to which was added daily, in a separate dish, 0.05 gram of a yeast concentrate powder. ${ }^{1}$ This group of animals in Table IV is numbered from $\mathrm{K}+\mathrm{B}_{21}$ to $\mathrm{K}+\mathrm{B}_{25}$, and as controls on this group there were five animals, $K+Y P_{1}$ to $K+Y P_{5}$, which were given the Kohman diet with addition, in a separate dish, of 0.05 gram of the yeast protein remaining from

\footnotetext{
1 This material was supplied by Mead Johnson and Company, and assayed by them to contain 80 units of vitamin $B_{1}$ and 35 units of vitamin $G$ per gram.
}

the concentrate powder after extraction of the B-complex. There were also two other control groups: $\mathrm{K}+\mathrm{CP}_{1}$ to $\mathrm{K}+\mathrm{CP}_{4}$, Kohman diet plus 0.05 grams of casein extracted free of B-complex given in a separate dish daily; and $K+G_{2}, K+G_{4}$, Kohman diet plus the equivalent amount of yeast concentrate which had first been autoclaved to destroy completely its vitamin $B_{1}$ content only, ${ }^{2}$ given in a separate dish daily. Thus all four of these groups did receive daily a very small amount of protein with or without vitamin G. In addition, vitamin $B_{1}$ was supplied in the form of a solution of the pure crystals (Merck) rather than by adding wheat-germ extract to the carrot diet. All of these small servings of protein with $B_{1}$ solution added, were, with few exceptions, completely consumed daily by the rats. The fact that these animals are all included in the second series of edematous rats (Table IV) records the result that they all showed retention of fluid in varying degree. Though there was a little delay, as compared to the group on the unmodified Kohman wet diet $\left(K_{21}\right.$ to $\mathrm{K}_{25}$ ), in the rapidity with which these animals lost weight from malnutrition and with which they accumulated fluid, the general trend was the same as the $K$ group, and there were no significant differences among the various groups outlined above. It was obvious then, that addition each day to the diet of 0.05 gram protein, whether this contained vitamin $G$ or not, was sufficient to defer slightly in some of the animals the effects of the unmodified Kohman diet. The individual animal that showed the greatest delay in becoming edematous can be seen from Table IV to be $\mathrm{K}+\mathrm{CP}_{1}$, which after 148 days of diet (the longest period) was still one of the least edematous animals of the whole group. The control normal group (Table III) had the Kohman wet diet with casein, extracted free of vitamin B-complex, replacing cornstarch in the amount of 20 per cent of the dry weight of the mixture. Three of the control animals $\left(K+C+B_{1}\right.$ to $\left.K+C+B_{4}\right)$ had in addition $0.05 \mathrm{gram}$ of the yeast concentrate added in a separate dish. ${ }^{8}$

The first series of protein-starved animals, $K_{3}$ to $K_{16}$, Table II, were all given their vitamin $B_{1}$ in wheat-germ

2 Assayed by Dr. Siegfried Maurer and found to contain a concentration of vitamin $G$ five times that of yeast.

8 Three litters of rats ( 27 in all) comprised all of these groups. There were representatives of each litter in each group. 
extract. The first series of normal animals, Table I, was composed of eight animals $\left(\mathrm{N}_{2}\right.$ to $\left.\mathrm{N}_{15}\right)$ on a varied, high vitamin diet (wheat germ, brewer's yeast, lettuce, bacon, cheese, and a paste of casein, starch, minerals, lard, butter, and cod-liver oil); and a group of four animals $\left(\mathrm{K}+\mathrm{C}_{1}\right.$ to $\left.\mathrm{K}+\mathrm{C}_{4}\right)$ on the Kohman wet diet with commercial casein replacing cornstarch in the amount of 15 per cent of the dry weight of the diet; and finally a group of four $\left(K+A_{1}\right.$ to $\left.K+A_{4}\right)$ on Kohman wet diet with egg albumin, extracted free of the Bcomplex, replacing cornstarch in the amount of 15 per cent of the dry weight.

In all of these diets, water was allowed ad libitum, though very little seemed to be taken by the rats, the fresh carrots satisfying their needs for water. The animals in all groups had beginning weights ranging from 68 grams to 105 grams. The youngest litter of known age was 49 days old when placed on the diets and the oldest was 69 days.

During the course of the protein-poor diets the weight curves showed a steady decline with small irregularities, and, after 9 or 10 weeks, occasional cycles of rapid gains and losses with some terminal rises due to sudden increases in fluid retention, as reported by others $(6,8)$. There is no need to show all of these curves here. There was seldom manifest edema or anasarca, though some had excessive pleural and peritoneal fluids when sacrificed (see Tables II and IV). The weight curves of the rats on normal and normal control diets showed satisfactory though not always maximal growths for these animals in all except the $\mathrm{K}+\mathrm{A}$ group, where the gains in weight were small and growth could hardly be called satisfactory. (In this connection see footnote 6 on page 358.)

\section{CHEMICAL DETERMINATIONS}

The first series of determinations are recorded for normal animals in Table I and for animals with various amounts of fluid retention in Table II. The determinations include: total serum nitrogen, muscle water, muscle protein nitrogen, muscle sodium and muscle potassium. The ratio, protein- $\mathrm{N}$ : potassium for muscle is shown, and the concentration of sodium plus potassium in millimoles per liter of total muscle water is given. There are also recorded figures for amounts of intracellular and extracellular water per kilogram of whole tissue and the concentration of potassium in intracellular water, derived by calculation, with certain assumptions which will be discussed later.

The second series of determinations are recorded for normal rats in Table III and for rats with varying degrees of edema in Table IV. These determinations include: $A$. For serum; total nitrogen, albumin nitrogen, and by difference, globulin nitrogen. $B$. For muscle; per- centage of water in whole wet tissue, percentage of water in fat-free tissue, 4 sodium and potassium in terms of fat-free wet tissue. The concentration of sodium plus potassium in millimoles per liter of total muscle water is also shown; and again, by calculations discussed later, the amounts of intracellular and extracellular water per kilogram of fat-free wet tissue and the concentration of potassium in intracellular water.

In Tables II and IV are also included determinations of sodium in six abdominal or chest fluids from edematous rats as indicated and in one subcutaneous fluid from a blister on the chest of rat $\mathrm{K}+\mathrm{B}_{24}$. The fluids found in seven more animals in these two series were either somewhat bloody or were obtained in too small an amount to make possible a sodium determination with the usual accuracy.

\section{METHODS}

The animals included in Tables I and II were sacrificed by a blow on the head. Because this often caused loss of a good deal of blood with the consequence that it was difficult to get blood from the heart in satisfactory amounts, the later groups, Tables III and IV, were sacrificed by piercing the medulla oblongata with a needle. From most of these latter enough blood was secured from the hearts to make possible determinations of serum albumin in addition to total serum proteins.

If there was any chest or abdominal fluid it was taken with a capillary pipette and transferred into a centrifuge tube. The blood was then taken from the heart by capillary pipette.

The animal was next placed in a closed chamber in which the atmosphere had been saturated with water vapor from a pan of water, and by inserting the hands through rubber tubes (sections of tire inner tubes attached to round openings in the chamber) the skinning of the legs, cutting off of the muscles, and placing them into weighing bottles could all be carried out within the chamber by vision through its glass top. This "humidor" was designed to prevent evaporation from the muscle during the handling. The weighing bottles having been previously weighed empty from a desiccator were allowed to come to temperature equilibrium in the " humidor" before being opened, so that no appreciable moisture would settle on the glass inside the bottles when opened. The tightly stoppered bottles containing the wet muscle were again brought to equilibrium in a desiccator for weighing the wet muscle. The tissue was then dried in an oven at $105^{\circ} \mathrm{C}$. Those included in Tables I and II were brought to constant weight in the milligram place, the larger samples (normals) re-

4 Fat extraction was suggested to us by Prof. A. B. Hastings. 
quiring as much as 19 days. Those in Tables III and IV, which were later to be extracted to remove fat, were dried to constant weight within $0.3 \mathrm{mgm}$., which required up to 35 days for samples up to 14 grams wet weight. It was hoped to eliminate moisture so completely from these samples that the later extraction with dry ethyl ether and petroleum would remove no salts. However, it was found in some preliminary experiments that from 2 to 5 per cent of the total amounts of sodium and potassium of the samples was removed during the extraction, whether because of moisture in the sample or in the ethyl ether, or whether because very minute scales of dried muscle tissue were sometimes lifted out with the capillary pipettes used in removing the extracting fluid. The last possibility hardly seems an adequate explanation of the transfer of so large an amount of base. At any rate, it was decided to evaporate the extracts in the quartz beakers in which the muscles were later to be ashed and thus, although a fat-free weight was obtained on the dry muscle for calculation, the extracted fats including whatever base was removed with them were ashed along with the fat-free tissue. This discussion obviously applies only to the determinations included in Tables III and IV since those included in Tables I and II were not made on fat-free tissues. The fat extractions were carried out according to the technique of Hastings and Eichelberger (10). The ashing of tissue in quartz with sulfuric acid has been described $(22,28)$.

The muscles analyzed in Tables I and II were not ashed in the same way, since determinations of muscle protein were made on these samples, and the bases had to be quantitatively extracted out of the dried mass. This was accomplished as follows: The tissue was allowed to stand covered with water until thoroughly soaked. Then enough trichloracetic acid was added to make a 20 per cent solution. After standing and macerating thoroughly in a mortar, the extract was filtered off and maceration was repeated with nine portions of 10 per cent trichloracetic acid while a quantitative transfer to the filter was accomplished. The extract was subsequently treated for phosphate precipitation before being made up to known volume, after which aliquot portions were used for dry ashing in platinum crucibles. This method of extraction was suggested by the procedure described by Salit (11) for sodium determinations in tissues. Six preliminary ashings of beef and rat muscle fibers, extracted in this way, convinced us that the bases were quantitatively extracted, since the total ash obtained in platinum crucibles from the protein remaining from 5 to 9 gram samples of muscle weighed only from 1 to 2 mgm., and being for the most part insoluble could be accounted for by glass ground off from the mortar. This ash contained indeterminable traces of sodium and potassium.

The muscle fiber having been quantitatively collected on a filter paper was transferred with the filter to a large Kjeldahl flask and digested for macro-Kjeldahl determinations. Aliquot portions of the digest were used for duplicate determinations which always agreed to 0.5 per cent.

Because of the variation in the amount of muscle fat and of the impracticability of mincing the material without loss of fluid, it was decided not to take two separate samples of muscle from one animal. There were two exceptions made. In Table I, analyses of two separate samples taken without mincing from Rat $\mathrm{N}_{9}$ are shown, and in Table III, analyses on two samples from Rat $\mathrm{K}+\mathrm{C}_{21}$ are presented. However, for the normal animals (Tables I and III), where the samples were of sufficient size duplicate determinations were made as follows: for those in Table I, after the extraction of the minerals and the phosphate precipitation in the extract; for those in Table III, after the ashing. For the values in Tables I and III the duplicate sodium determinations agreed to within 3 per cent and the duplicate potassium determinations to within $11 / 2$ per cent. There was one exception to each of these standards; namely, the sodium determinations for $\mathrm{K}+\mathrm{C}_{25}$ were 7 per cent apart, and the potassium determinations for the second samples of $\mathrm{K}+\mathrm{C}_{21}$ were 14 per cent apart. In each of these two instances the single value that seemed the more reasonable is given in the Table and used for subsequent calculations. We obtained theoretical recoveries of sodium and potassium from known mixtures of $\mathrm{NaCl}$, $\mathrm{K}_{2} \mathrm{SO}_{4}$, and $\mathrm{H}_{3} \mathrm{PO}_{4}$ when put through separate phosphate precipitations before the ashings in platinum, or when put through separate ashings in quartz. Sodium and potassium determinations on muscle extracts in which the phosphate precipitation was done in duplicate agreed to 3 per cent and 1 per cent, respectively. Known amounts of these bases added to the extracts were recovered quantitatively. Duplicate ashings, in quartz, of dried ground homogeneous beef samples yielded sodium and potassium determinations which agreed to $11 / 2$ per cent.

The samples from the undernourished edematous animals and from the $\mathrm{K}+\mathrm{A}$ group of Table $\mathrm{I}$ were so small that the material could not be divided for the duplication of even the final steps in the sodium and potassium determinations. In the case of protein nitrogen, duplicate determinations were made just as for normal animals. The single determinations in Tables II and IV ought to be dependable, granting always a possibility of some bad error committed unconsciously, which would bring a determination far out of line.

The final chemical methods used were the following.

1. Removal of phosphate. (a) In trichloracetic acid extracts from muscles listed in Tables I and II (first series), the method of phosphate removal was based on that given by Hoffman (12) in preparation for total base determinations in urine. It was modified to the extent that the solutions were not transferred to volumetric flasks until after the precipitate of ferric ammonium acetate was well coagulated and all evolution of gases had ceased. Then, aliquot portions of filtrate were evaporated down with 3 cc. of $1: 1 \mathrm{H}_{2} \mathrm{SO}_{4}$ in platinum crucibles for dry ashing. The ashing was 
TABLE I

Normal rats-first series

\begin{tabular}{|c|c|c|c|c|c|c|c|c|c|c|c|}
\hline \multirow{2}{*}{$\begin{array}{c}\text { Number } \\
\text { of } \\
\text { rat }\end{array}$} & \multirow{2}{*}{$\begin{array}{c}\text { Diet } \\
\text { period }\end{array}$} & \multirow{2}{*}{$\begin{array}{c}\text { Serum } \\
\text { total } \\
\text { nitro- } \\
\text { gen } \\
\text { per } \\
100 \mathrm{cc} \text {. } \\
\times 6.25\end{array}$} & \multicolumn{9}{|c|}{ Muscle } \\
\hline & & & $\begin{array}{c}\text { Water } \\
\text { of } \\
\text { whole } \\
\text { tissue }\end{array}$ & $\underset{\text { nitrogen }}{\text { Protein }}$ & Sodium & $\begin{array}{l}\text { Potas- } \\
\text { sium }\end{array}$ & $\begin{array}{l}\text { Extracellular } \\
\text { fluid }\end{array}$ & $\begin{array}{l}\text { Intracellular } \\
\text { water }\end{array}$ & $\begin{array}{l}\text { Potas- } \\
\text { sium }\end{array}$ & $\begin{array}{c}\text { Sodium } \\
+ \\
\text { potas- } \\
\text { sium }\end{array}$ & $\begin{array}{c}\text { Protein } \\
\text { nitrogen } \\
\text { potassium }\end{array}$ \\
\hline & days & & per cent & \multicolumn{3}{|c|}{ mM. per kgm. of whole tissue } & \multicolumn{2}{|c|}{ ml. per kgm. of whole tissue } & $\begin{array}{l}\text { mM. } \\
\text { per liter } \\
\text { cell water }\end{array}$ & $\underset{\substack{\operatorname{mer} \\
\text { total } \mathrm{H}_{3} \mathrm{O}}}{\operatorname{mit}}$ & ratio \\
\hline
\end{tabular}

ON VARIED NORMAL DIET

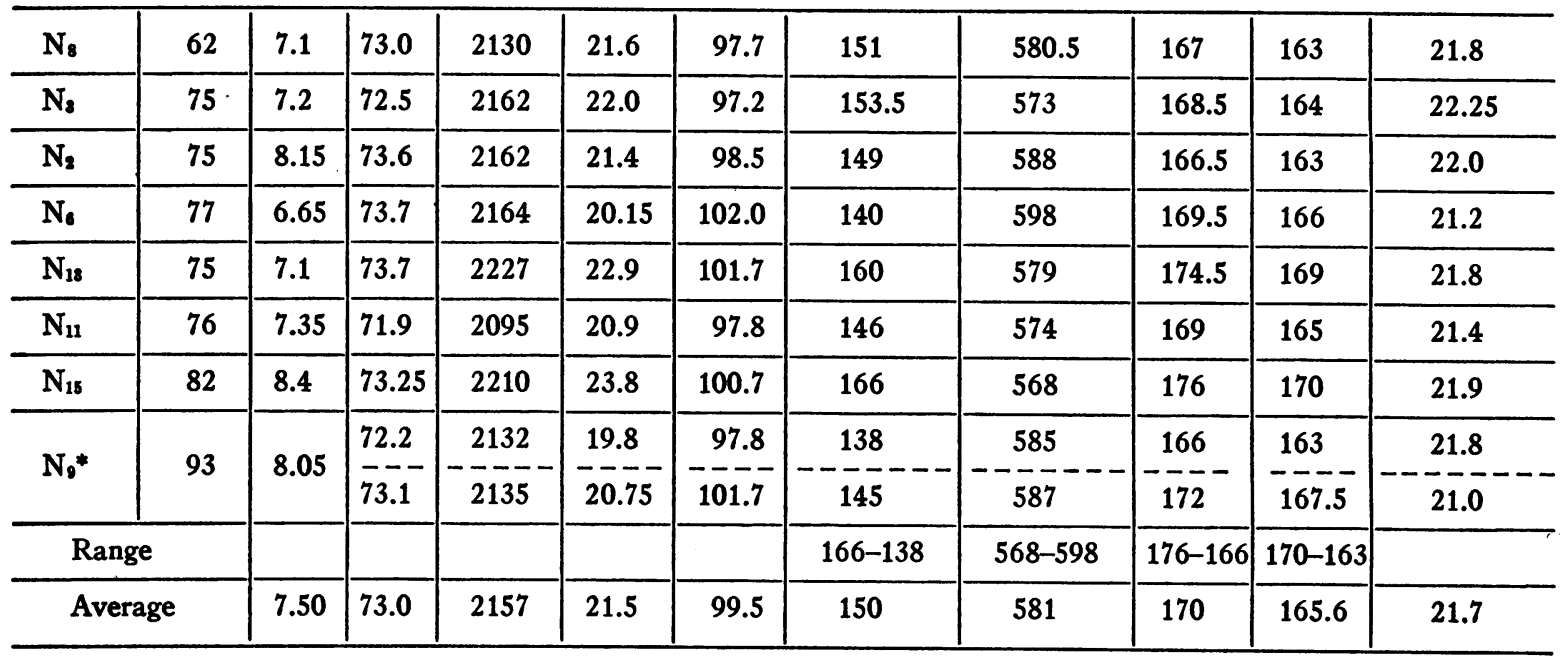

ON CARROT CONTROL DIET-KOHMAN DIET + CASEIN

\begin{tabular}{c|c|c|c|c|c|c|c|c|c|c|c}
\hline $\mathrm{K}+\mathrm{C}_{4}$ & 79 & 6.6 & 73.25 & 2134 & 22.1 & 99.8 & 154 & 579.5 & 171 & 166.5 & 21.4 \\
\hline $\mathrm{K}+\mathrm{C}_{1}$ & 82 & 6.9 & 74.2 & 2095 & 20.7 & 105.6 & 144.5 & 599 & 175 & 170 & 19.8 \\
\hline $\mathrm{K}+\mathrm{C}_{2}$ & 86 & 7.5 & 73.85 & 2204 & 19.8 & 103.5 & 138 & 601.5 & 171 & 167 & 21.3 \\
\hline $\mathrm{K}+\mathrm{C}_{2}$ & 93 & 7.9 & 74.3 & 2201 & 24.3 & 99.5 & 169.5 & 575 & 172 & 167 & 22.1 \\
\hline \multicolumn{2}{c}{ Range } & & & & & & $169-138$ & $575-601$ & $175-171$ & $170-166$ & \\
\hline \multicolumn{2}{c|}{ Average } & 7.2 & 73.9 & 2158 & 21.7 & 102.1 & 151.5 & 589 & 172 & 167.5 & 21.15 \\
\hline
\end{tabular}

ON CARROT CONTROL DIET-KOHMAN DIET + EGG ALBUMIN†

\begin{tabular}{c|c|c|c|c|c|c|c|c|c|c|c}
\hline $\mathrm{K}+\mathrm{A}_{\mathbf{4}}$ & 82 & 6.5 & 75.0 & 2173 & 26.5 & 102.0 & 185 & 567 & 178.5 & 171 & 21.3 \\
\hline $\mathrm{K}+\mathrm{A}_{\mathbf{3}}$ & 103 & 5.05 & 74.8 & 2100 & 24.7 & 103.2 & 172 & 577 & 177.5 & 171 & 20.3 \\
\hline $\mathrm{K}+\mathrm{A}_{2}$ & 126 & 6.35 & 75.0 & 2150 & 27.15 & 97.9 & 189.5 & 562.5 & 172.5 & 167 & 22.0 \\
\hline $\mathrm{K}+\mathrm{A}_{1}$ & 131 & 6.5 & 74.2 & 2190 & 21.1 & 105.7 & 147 & 596 & 176 & 171 & 20.7 \\
\hline Range & & & & & & $189-147$ & $562-596$ & $178-172$ & $171-167$ & \\
\hline \multicolumn{1}{c}{ Average } & 6.1 & 74.8 & 2153 & 24.9 & 102.2 & 173.5 & 575.5 & 176 & 170 & 21.1 \\
\hline Complete range & & & & & & $189-138$ & $562-601$ & $178-166$ & $171-163$ & \\
\hline Complete average & 7.1 & 73.5 & 2157 & 22.3 & 100.7 & 156 & 581 & 172 & 167.1 & 21.4 \\
\hline
\end{tabular}

* Two samples.

† See footnote 6 on page 358. 
done in duplicate for the large samples but not for the small.

(b) In the aliquots of ash used for sodium determinations on the muscles listed in Tables III and IV (second series), the method of phosphate removal described by Butler and Tuthill (13) was used.

2. Sodium. The solutions for sodium determinations were evaporated to dryness in $30 \mathrm{cc}$. beakers, and the procedure of Butler and Tuthill (13) was followed.

Barber and Kolthoff (14) have stated that a contaminating precipitation of the potassium triple salt occurs only in the presence of more than $50 \mathrm{mgm}$. of $\mathrm{KCl}$ per cc., while a precipitation of some $\mathrm{K}_{2} \mathrm{SO}_{4}$ itself may occur in the presence of somewhat smaller amounts of $\mathrm{K}_{2} \mathrm{SO}_{4}$. Butler and Tuthill have accepted this finding. Nevertheless, we found that sodium precipitates obtained from the muscles (either series) and also from known mixtures of $\mathrm{K}_{2} \mathrm{SO}_{4}$ and $\mathrm{NaCl}$ of approximately muscle propor- tions contained some potassium. Mond and Netter (15) also found sodium determinations on muscle tissues to be higher than their true values when made as uranylzinc-sodium-acetate precipitates in the presence of the muscle potassium. We therefore worked out a correction curve for the increase in weight of sodium precipitate with increasing amounts of potassium present, making due allowance for sodium blanks on the potassium sulfate used in the known mixtures. From this curve was taken the absolute weight increment to be subtracted from any given weight of sodium precipitate, on the basis of the amount of potassium known to be present in the given solution from the potassium value determined on another aliquot of the same ash. These corrections ran from 0 to $3.1 \mathrm{mgm}$. for the presence of 6 to $20 \mathrm{mgm}$. of potassium in the $2 \mathrm{cc}$. of solution used for sodium determination. It was only in the cases of the larger amounts of potassium that the correction was of an order of magni-

TABLE II

Edematous rats-first series

(Listed in order of increasing water content in whole tissue)

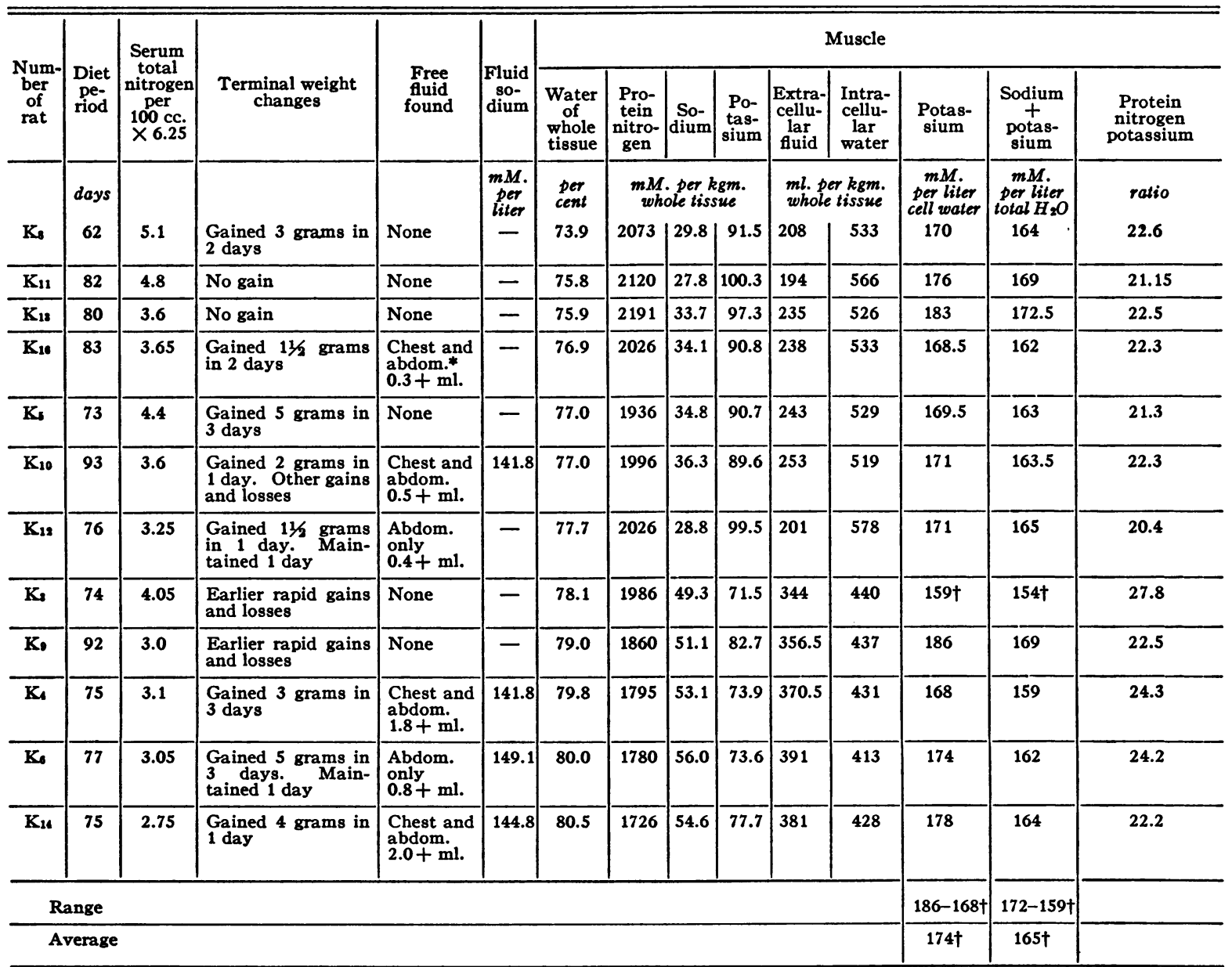

* abdom. = abdominal.

† From the figures of both range and average the values for $K_{3}$ have been omitted-see discussion. 
TABLE III

Normal rats-second series

\begin{tabular}{|c|c|c|c|c|c|c|c|c|c|c|c|c|}
\hline \multirow{3}{*}{$\begin{array}{c}\text { Number } \\
\text { of } \\
\text { rat }\end{array}$} & \multirow{3}{*}{$\begin{array}{c}\text { Diet } \\
\text { pe- } \\
\text { riod }\end{array} \mid$} & \multicolumn{3}{|c|}{$\begin{array}{c}\text { Serum nitrogen } \\
\times 6.25 \text { per } 100 \text { cc. }\end{array}$} & \multicolumn{8}{|c|}{ Muscle } \\
\hline & & \multirow[b]{2}{*}{ Total } & \multirow[b]{2}{*}{$\begin{array}{c}\text { Albu- } \\
\min \end{array}$} & \multirow[b]{2}{*}{$\begin{array}{c}\text { Glob- } \\
\text { ulin }\end{array}$} & \multicolumn{2}{|c|}{ Water } & \multirow[b]{2}{*}{ Sodium } & \multirow[b]{2}{*}{ Potassium } & \multirow[b]{2}{*}{$\begin{array}{l}\text { Extracellular } \\
\text { fluid }\end{array}$} & \multirow[b]{2}{*}{$\begin{array}{c}\text { Intracellular } \\
\text { water }\end{array}$} & \multirow[b]{2}{*}{$\begin{array}{l}\text { Potas- } \\
\text { sium }\end{array}$} & \multirow{2}{*}{$\begin{array}{c}\text { Sodium } \\
+ \\
\text { potassium }\end{array}$} \\
\hline & & & & & $\begin{array}{c}\begin{array}{c}\text { Of } \\
\text { whole } \\
\text { tissue }\end{array} \\
\text {. }\end{array}$ & $\begin{array}{c}\text { Of } \\
\text { fat } \\
\text { free }\end{array}$ & & & & & & \\
\hline & days & & & & $\begin{array}{l}\text { per } \\
\text { cent }\end{array}$ & $\begin{array}{l}\text { per } \\
\text { cent }\end{array}$ & \multicolumn{2}{|c|}{$\begin{array}{c}\text { m.eq. per kgm. of } \\
\text { fat-free tissue }\end{array}$} & \multicolumn{2}{|c|}{$\begin{array}{c}\text { ml. per kgm. of } \\
\text { fal-free tissue }\end{array}$} & $\begin{array}{c}\text { mM. } \\
\text { per liter } \\
\text { cell water }\end{array}$ & $\underset{\substack{\text { per liter } \\
\text { total } \mathrm{H}_{2} \mathrm{O}}}{\min }$ \\
\hline $\mathrm{K}+\mathrm{C}+\mathrm{B}_{\mathbf{2}}$ & 84 & 8.5 & 4.15 & 4.35 & 72.65 & 77 & 25.5 & 93.1 & 178 & 595 & 155 & 154 \\
\hline $\mathrm{K}+\mathrm{C}_{22}$ & 76 & 7.45 & 3.6 & 3.85 & 73.9 & 77.35 & 23.8 & 108.8 & 166 & 609 & 177.5 & 171 \\
\hline $\mathrm{K}+\mathrm{C}+\mathrm{B}_{\mathbf{1}}$ & 147 & 7.65 & 4.45 & 3.2 & 74.4 & 76.9 & 21.95 & 97.4 & 153 & 617 & 157 & 155 \\
\hline $\mathrm{K}+\mathrm{C}_{21} *$ & 147 & 7.3 & 3.7 & 3.6 & $\frac{75.35}{76.0}$ & $\mid \begin{array}{l}76.65 \\
77.3\end{array}$ & $-\frac{19.25}{19.25}$ & $-\frac{98.0}{102.9}$ & $--\frac{134}{134}-$ & $-\frac{633.5}{640}$ & $\frac{154}{160}$ & $-\frac{153}{158}-$ \\
\hline $\mathrm{K}+\mathrm{C}+\mathrm{B}_{4}$ & 144 & 7.45 & 3.75 & 3.7 & 71.3 & 76.65 & 27.2 & 99.2 & 190 & 578.5 & 170 & 165 \\
\hline $\mathrm{K}+\mathrm{C}_{25}$ & 102 & 8.85 & 4.15 & 4.7 & 74.45 & 77.1 & 23.3 & 96.3 & 163 & 610 & 157 & 155 \\
\hline $\mathrm{K}+\mathrm{C}_{2 \mathrm{~s}}$ & 144 & 7.5 & 3.7 & 3.8 & 74.0 & \multicolumn{2}{|c|}{ Not completed } & & & & & \\
\hline Range & & & & & & & & & $190-134$ & $578-640$ & $177-154$ & $171-153$ \\
\hline Average & & 7.8 & 3.9 & 3.9 & 74.0 & 77.0 & 22.9 & 99.4 & 160 & 612 & 161.5 & 158.7 \\
\hline
\end{tabular}

* Two samples.

tude equal to or larger than the experimental error of the sodium method. However, the proportionate correction was applied to all weights. The removal of potassium with saturated ammonium perchlorate solution proved to be much more tedious and to bring about results on known sodium solutions that were approximately 2 per cent low.

3. Potassium. The aliquots of ash for potassium determinations in both series were evaporated to dryness in $30 \mathrm{cc}$. beakers, and the potassium determinations were made by the Shohl and Bennett (16) method using their colorimetric procedure.

In edema fluids the protein was removed with 20 per cent trichloracetic acid and for sodium determination an aliquot of the filtrate was transferred directly to the uranyl-zinc-acetate reagent in the glass filter.

The serum albumin and globulins were separated by the method of Howe (17). All serum nitrogen determinations were done by the Koch and McMeekin (18) micro-Kjeldahl method.

Blanks on all reagents used in all procedures were determined repeatedly.

\section{Discussion of tables}

\section{The normal rats}

In Table I, the animals are not listed in a particular order. They are, however, grouped according to diet, and the litter mates are listed in succession. In Table III, the second group of normals is arranged also with litter mates in succession, the two diets being differentiated by the numbers assigned to the animals. In comparing the two tables of normals it is to be noted that the average percentage of water in the whole muscle of rats in Table III agrees very closely to that found for the previous $\mathrm{K}+\mathrm{C}$ group, that the $\mathrm{N}$ group is about 1 per cent lower and the $\mathrm{K}+\mathrm{A}$ group about 1 per cent higher. ${ }^{5}$ The maximum variation in water among the animals in any diet unit in Table I, however, is 2 per cent, while the variation in Table III reaches almost 5 per cent in the water figures. It is interesting to see that the percentage of water based on fatfree tissue has greater constancy than the percentage of water of whole tissue. The variation between extreme values in fat-free tissues does not exceed 0.7 per cent. This extreme variation of the whole group is shown between the two samples from one animal, $\mathrm{K}+\mathrm{C}_{21}$. The average for fat-free tissue is 3 per cent higher than the average for whole tissue. The 5 per cent varia-

\footnotetext{
5 See footnote 6 on page 358 .
} 
tion noted in this series in terms of whole tissue can, then, be explained chiefly as due to variations in fat content of the whole tissues.

Surprisingly enough, there is no greater con- stancy in sodium and in potassium figures in the fat-free tissue of the normal animals in Table III than in the corresponding figures based on whole tissue of the normal animals in Table I. One

TABLE IV

Edematous rats-second series

(Listed in order of increasing water content in fat-free tissue)

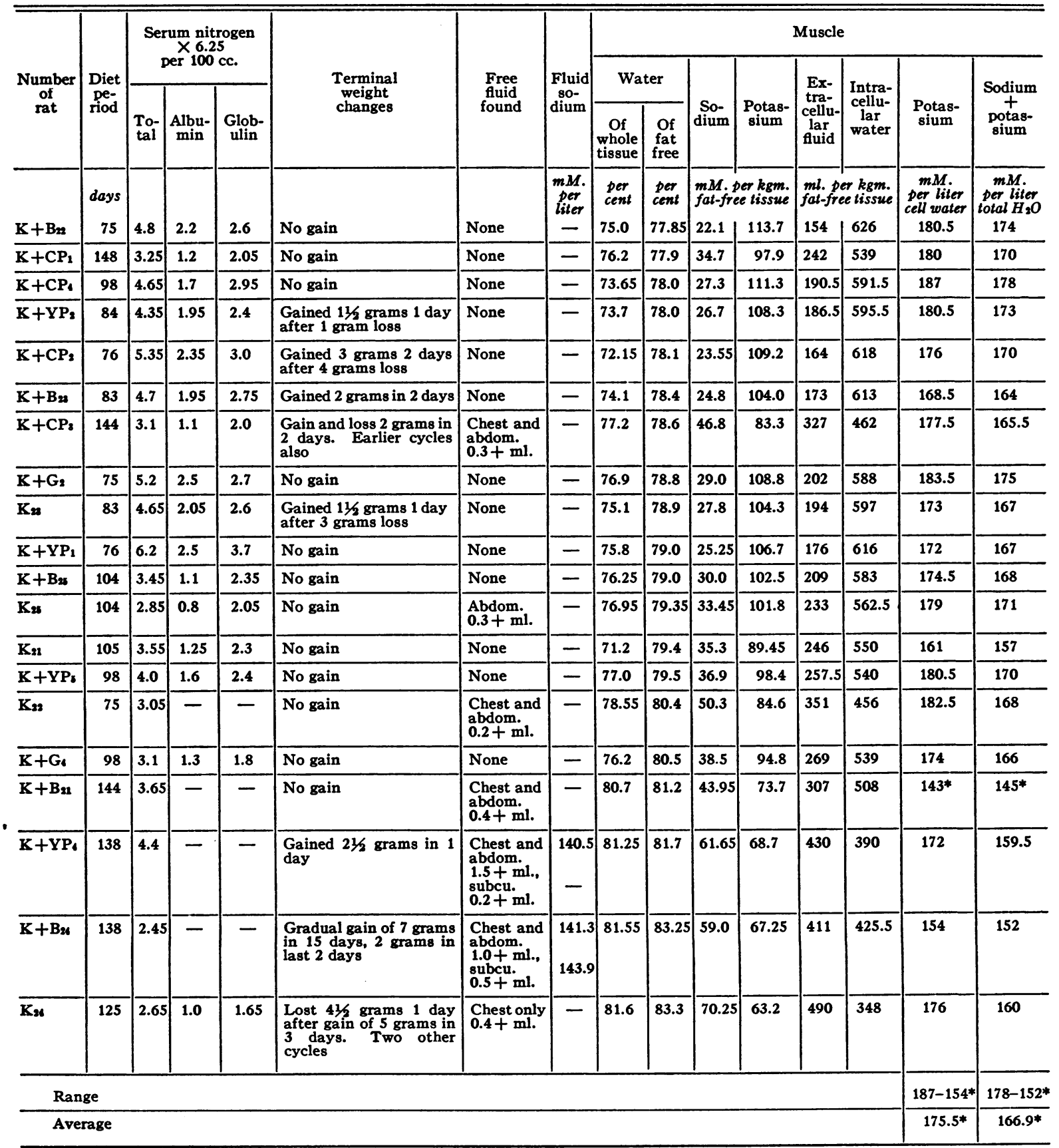

* From the figures of both range and average the values for $\mathrm{K}+\mathrm{B}_{21}$ have been omitted since it seems not unlikely that their extreme lowness is due to technical error. 
might have expected that these bases, which are presumed to be in solution in the muscle water, would follow water in showing less variation when based on fat-free tissue. The variation in potassium of this fat-free series is, in fact, greater than that in the other series and taken by itself the $\mathrm{N}$ group of animals, made up of a variety of litters but all on the same non-carrot normal diet, shows the greatest constancy in sodium and potassium figures even in terms of tissue which must have had some variations in fat content. From this it might be inferred that the animals on the control carrot diets, and especially those of the second series, had larger variations in the relative amounts of their intracellular and extracellular muscle water than the $\mathrm{N}$ series. The possibility of less accuracy in the method of ashing in quartz, used preparatory to these determinations in the second series, was considered, but from the ashings of known salts we could get no evidence of less reliability in this procedure than in our previous procedure of extraction plus ashing in platinum. The final chemical methods used in both series were the same.

The serum albumin and globulin figures recorded for normal rats in Table III indicate that the serum albumin: globulin ratio in white rats is 1 as contrasted with about 2 for this ratio in man.

\section{The edematous rats}

In Table II the animals are listed in the order of increasing water content in whole tissue, in Table IV in the order of increasing water content of fat-free wet tissue. There is a very rough correlation of increasing water contents with decreasing serum total nitrogen and serum albumin figures. This correlation which is better when calculated extracellular fluid contents are compared with serum protein values will be discussed below.

\section{Calculations}

The calculation of extracellular fluid was based on the assumptions that all the sodium of the muscle is in the extracellular fluid and that its concentration in this fluid is $143.3 \mathrm{mM}$. per liter of fluid, which is the mean of the seven values determined for the concentration of sodium in free fluids from edematous rats. The cell water was calculated by difference between fluid water and total water (using 99 per cent of the fluid value as its water value). Finally, having made an allowance of $4 \mathrm{mM}$. of potassium per liter of extracellular fluid (this being the medium value for potassium from among those reported for various edema fluids by several authors $(19,20$, 21)) the concentration of the remaining potassium in the cell water was calculated. Because of physiological variation of sodium concentration in extracellular fluid a mean value cannot be considered as accurate for any individual animal even if it is based on more determinations than we had. Since a constant value (143.3) was used for all our animals as a basis for the several calculations, the inaccuracy involved here must be reflected in an exaggerated variation between animals in the final calculated result; namely, the potassium concentration in the cell water.

The validity of the assumption that all muscle sodium is in extracellular fluid is discussed below. So also is the consideration that the concentration of sodium in this fluid should have a slightly different value in the fluid of the normal animal than that found in the edema fluids. Hastings and Eichelberger (10) and Harrison, Darrow and Yannet (22) base their calculations on the assumption that chloride is present only in extracellular fluid and on chloride concentrations found for each animal by applying the Donnan ratio to the individual serum chloride figures.

\section{DISCUSSION \\ Relation of edema fluid in muscle to serum protein levels}

In the figures for extracellular fluid content of muscle at different serum protein levels we have quantitative evidence that the muscle tissue becomes slightly edematous with the first decrease of serum protein, and that it becomes increasingly so with decreasing serum proteins. ${ }^{\circ}$ This rela-

${ }^{6}$ The four animals, $K+A_{1}$ to $K+A_{4}$, though they are included in Table $I$ as normal animals, ought probably to be considered as on the borderline of fluid retention. Their diet was hardly adequate in protein for growth, and this is reflected in a tendency to lower serum protein as compared to other normals, and a tendency to slightly higher muscle sodium and water values. The average calculated extracellular water figure for this group is consequently somewhater higher than that of the other normal groups. 
tionship is plotted in Figure 1. It shows that there are increasing slight accumulations of edema fluid in the muscle while the serum total protein values are dropping from 6.5 to 4.5 , the serum albumin values from 3.5 to 2.0 , and that the accumulation of fluid becomes progressively greater when the serum total protein falls below 4.5 per cent and the albumin below 2.0 per cent. Weech, Snelling and Goettsch (23) studied the behavior of weight curves and their relation to
The theory of a "critical level of plasma proteins" which must be reached before edema occurs has grown out of the circumstance that the presence of edema can usually be ascertained only by such gross methods as the following: body weight increase, palpability, swelling of parts and occurrence of free fluid in the cavities. Moreover, a completely rational filtration theory for the mechanism of edema formation must include the conception that filtration begins with the first

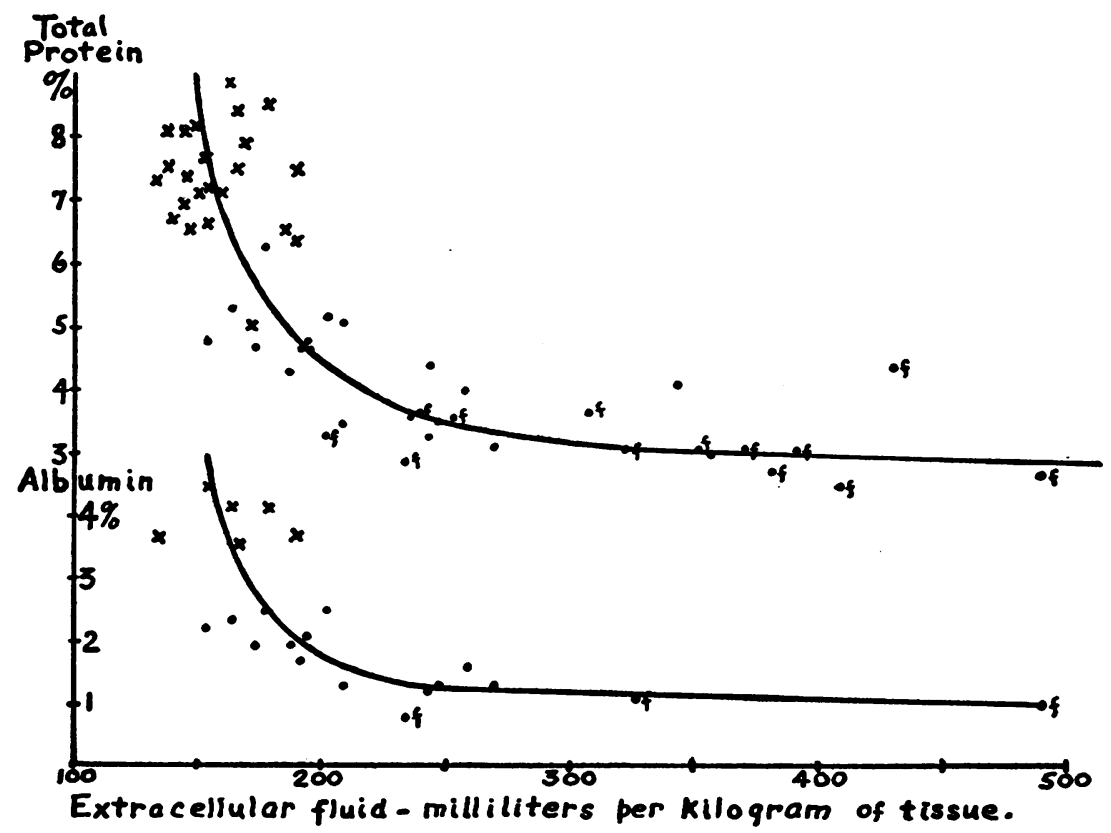

Fig. 1. The Relation of the Extracellular Flutd Content of Muscle to the Serum Total Protein and Albumin Values.

The crosses represent values for normal animals and the dots for edematous animals. The symbol $f$ indicates that free fluid was found in these animals. The extracellular fluid values per kilogram of whole tissue (Tables I and II) are plotted on the same scale as the extracellular fluid per kilogram of fat-free tissue (Tables III and IV).

declining plasma proteins as well as sodium, chloride, and nitrogen balances in dogs with nutritional and plasmapheresis edemas. They conclude that there is no indication of "the existence of a 'margin of safety' in the plasma oncotic pressure which must be exceeded before retention of salt and water begins" and that their "data argue in favor of gradual fluid retention which seems to accompany the entire process of plasma protein depletion." It seems likely to us that this situation exists in the tissues during the course of plasma protein depletion in nephrosis, also. decrease of the plasma oncotic pressure below the level of the balancing pressures.

Relation of muscle protein nitrogen to potassium

In the normal rats of Table I the ratio of muscle protein nitrogen to muscle potassium has extreme values as far apart as $\mathbf{1 1 . 4}$ per cent of the average ratio. It would seem then that as related to cell protein the variation in amounts of cell water, if this is determined by a constant concentration of potassium, can reach the extreme of about 12 per cent in normal tissues. If not, 
the variability in the ratio must be a combination of variations in concentration of potassium in cell water and in the amounts of cell water as compared to cell protein. In giving this significance to the ratio of protein-nitrogen to potassium the small amount of potassium in extracellular water is disregarded. Gamble, Ross and Tisdall (24) used the concept of a constant relationship of cell protein to cell water, together with their findings of potassium and nitrogen excretion during starvation, as a basis for calculating intracellular water lost by protein metabolism, and, by difference, the amount of intracellular water lost due to reduction of cell volume. The latter, they consider, is roughly determined by the amount of glycogen depletion. Lavietes, D'Esopo and Harrison (25) review Gamble's reasoning and point out that the possibilities of large variations in cell water without " change of nitrogen or glycogen or even potassium balance as the result of a change in the molar concentration of the body water as a whole through the addition or removal of water without base or a change in the concentration of sodium in interstitial fluids, which necessitates an exchange of water with the cells in order to restore osmotic equilibrium " make it unreasonable to assume that "cellular protein or glycogen is associated in such fixed proportion with water that the excretion of one inevitably entails the elimination of an equivalent amount of the other."

It was therefore not to be expected that in the course of progressing edema and starvation the ratio of protein-nitrogen to potassium should be maintained at a constant level, but with such a range of variation in normals it is perhaps not surprising that nine out of twelve of the rats in Table II did maintain a ratio of muscle-proteinnitrogen: potassium in the normal range or very near its upper limit. Among these nine were two of the most edematous animals in the group. The nine ratios average somewhat higher (21.9) than the normal average (21.4), indicating perhaps a tendency to some loss of cell water accompanied by potassium beyond that from protein metabolism or a tendency to lowered potassium concentration in the cell water. The three remaining quite edematous animals showed a high ratio of nitrogen to potassium, which means either a loss of water and its base out of the cells beyond the loss by protein metabolism or else a dilution of potassium within cell water. The latter alternative is not consistent with the results in general from calculations of potassium concentration based on the intracellular water values, but in the case of $\mathrm{K}_{3}$ which has the highest ratio, it appears that there may be an unusual dilution of potassium. However, a gross error in the potassium determination of this one muscle could account for both the high ratio of its protein nitrogen to potassium and the low calculated potassium concentration.

\section{Osmolal concentrations of bases in the two com-} partments of tissue water

We are indebted to Prof. A. B. Hastings for his aid in clarifying our concept of how the values of the various constituents of a tissue in terms of a unit weight of tissue are affected by addition of water to that tissue. In considering the amount of fluid retention in any tissue it is misleading to use the water percentage or grams of water per kilogram of the original (normal) tissue as a basis from which to calculate the retention in the edematous tissue. A muscle, for example, which had $750 \mathrm{cc}$. of water per kilogram to begin with has had $250 \mathrm{cc}$. of water added to each kilogram of original tissue to make it an edematous muscle containing $800 \mathrm{cc}$. of water per kilogram. In other words the fluid added is 25 per cent of the original weight of tissue rather than only 5 per cent. Or, more simply, from the solids standpoint the 25 per cent solids are diluted to 20 per cent solids which means a change to $5 / 4$ of the original bulk or addition of water equal to $1 / 4$ the original weight. In the new kilogram of tissue then, there is $\frac{1000}{1250} \times 250 \mathrm{cc} .=200 \mathrm{cc}$. of the retained water and the equivalents of sodium and chloride ions retained with it. Now, if originally, all the sodium and chloride ions in the kilogram of tissue were in solution in $150 \mathrm{cc}$. of its water (extracellular portion) and $\frac{1000}{1250}$ of the original amount of sodium and of chloride ions is present in the kilogram of new tissue, the new kilogram of muscle now contains sodium and chloride ions in amounts equivalent to $120+200$ cc. of water if the sodium and chloride ions were 
added in the same concentrations as those in the original extracellular water (plasma filtrate concentrations). Hence the quantity of sodium and of chloride ions has increased per kilogram of tissue from an amount equivalent to $150 \mathrm{cc}$. of water to an amount equivalent to $320 \mathrm{cc}$. of water. Each will have more than doubled in value, then, while the water figure has increased only by $1 / 5$ of its original value. The increase in sodium and chloride values per kilogram of tissue will be related to the increase in water value as 170 is to 50 which would seem to make the added sodium and chloride ions 3.4 times as concentrated in the added water as they really are. In this fact lies the fallacy of Lepore's (26) conclusion that chloride found in the muscle was "stored hypertonically." As Peters (27, page 137) points out " no interpretation can be made without knowledge of the total osmolar concentration in the interstitial fluids at the beginning and at the end of each experiment," and for this knowledge more complete data are required. However, it is not necessary to assign the great variability and the large values of Lepore's " molarity of stored chloride" to "large technical errors" as is done by Peters. Such variability and such apparently tremendous excesses of chloride as compared to water excesses are entirely possible when the figures are treated in that way. In the instances of only 1 per cent increase of water content in a tissue the discrepancies of excess chloride compared to excess water figures explainable by the above can even be more than doubled if the average normal value for water (used as a basis for calculation) happens to be off by 1 per cent or more of what is really normal for that individual animal. There is enough variability in the water of muscles of normal animals when fat is not extracted so that an average value may easily be 1 to 2 per cent off for an individual specimen. Hence molarity figures for chloride in the neighborhood of 1.0, as several that occur in Lepore's report, which are 8 to 9 times plasma filtrate molarity, are explainable by combination of this circumstance with the fallacious handling of figures as outlined above.

Though the calculations of amounts of extracellular water, and by difference, amounts of intracellular water, could be done with more assurance on the basis of chloride determinations than on the basis of sodium, since all experimental evidence seems to point to the conclusion that no chloride whatever is to be attributed to muscle cells (Peters $(27$, pages 132,133$)$ ) yet the broad conclusion of other workers that probably also no sodium is to be found in skeletal muscle cells (Peters $(27$, pages 129,130$)$ ), gives us this basis for using our sodium figures. With the findings of Hastings and Eichelberger (10) in mind that "approximately $5 \mathrm{mM}$. of sodium per kilo of tissue" in dog muscle is attributable to the muscle cells, and the following conclusion of Harrison, Darrow, and Yannet (22) in mind also, that, " except for the skeletal sodium and 10 per cent of the sodium of dog muscle, all of the sodium of the body can be accounted for in the same volume of extracellular water which would contain the body chloride," we admit the possibility that from 10 to 20 per cent of our sodium in normal muscles should be excluded from calculation as osmotically active extracellular sodium. ${ }^{7}$ Harrison, Darrow and Yannet found practically no " extra sodium" in the separate muscle determinations in rabbits, however. No one has reported the relationship of the muscle sodium to muscle chloride for rats, and it is to be regretted that we do not have the necessary data to do so. However, with 15 per cent allowance for "extra sodium" our several nor$\mathrm{mal}^{8}$ averages for extracellular fluid would be lowered to $127 \mathrm{ml}$. ( $\mathrm{N}$ group), $129 \mathrm{ml}$. ( $\mathrm{K}+\mathrm{C}_{1}$ to $\mathrm{K}+\mathrm{C}_{4}$ ), and $136 \mathrm{ml}$. (Table III). As they now stand the averages are 150,151, and 160 , respectively. All of the extracellular water values in normal rats, as they stand without correction for " extra sodium," come within the range of 13 to 20 per cent of the muscle weight. This is in agreement with the more or less general conclusion from a variety of investigations concerning the amount of interstitial fluid in muscle tissue (Peters $(27$, pages $128,130,134,141))$. With a

\footnotetext{
7For discussion of " extra sodium" see Peters (27, pages 139 to 142 ). As a result of many perfusion experiments with frog legs, Mond and Netter (15) come to the conclusion that there is sodium in an amount up to $30 \mathrm{mgm}$. per cent which is not balanced by chloride, bound in some way to the surface of the muscle fiber.

8 Excluding the $\mathrm{K}+\mathrm{A}$ group, see footnote 6 on page 358.
} 
15 per cent allowance for "extra sodium" the great majority of extracellular water figures in normal rats would fall below $150 \mathrm{ml}$. or 15 per cent of the whole tissue, and would range down to 11 per cent of the whole tissue. This range has some support also from the figures for interstitial fluid in muscle of dogs calculated by Peters (27, page 135) on the basis of Lepore's figures.

To carry along the effect of a 10 to 20 per cent change in extracellular water figures into the subsequent calculations would mean a $21 / 2$ to 5 per cent decrease in the concentration of potassium in the intracellular water. Since our figures from normal rats for potassium concentration in intracellular water seem to run somewhat high (154 to 178) as compared to those given for muscle and various other tissues in various animals (22) (muscle: one dog, 132; one monkey, 143; one rabbit, 122; other tissues: 109 to 155 ) it might be argued that the "extra sodium" allowance would bring them closer to other muscle figures. However, it might equally well be argued, as shown above, that it would bring the extracellular water figures out of line with those reported figures that are in the neighborhood of 17 to 20 per cent (Peters (27, pages 130,134, 141)). Besides, our figures for concentration of sodium plus potassium in total water also average higher than other reported figures. Light, Smith, Smith and Anderson (28) give figures ranging from 125.4 to 176.6 on whole rat bodies, and Harrison, Darrow, and Yannet (22) show results for muscle of one dog, 144; one monkey, 149; one rabbit, 127; while for other tissues in these animals they give sodium plus potassium concentration ranging from 139 to 175 . The range of 153 to 171 covers all of our sodium plus potassium concentrations per liter of total muscle water in normal rats. Our average in Table III is no higher than the one figure calculated from the Katz analysis of human muscle as shown by Peters (27, page 129) though the relative amounts of sodium and potassium are quite different from these figures for human muscle, and as Peters points out the Katz figures seem to run higher than other reported muscle figures. At any rate, for a comparative study as between normal and edematous rats, of the osmotic concentrations of potassium or sodium in their respective compartments of water, the "extra sodium" can be disregarded.

\section{Relation to edema}

In general, the relations of sodium and potassium to muscle water in our rats with a nutritional edema and hypoproteinemia are such as to indicate that the stored sodium and water can be entirely accounted for by an accumulation of ultrafiltrate of the plasma. The extracellular fluid per kilogram of tissue may reach an amount as great as three times the normal with no significant change in the osmolal concentrations in the two compartments of muscle water. This is the broad conclusion resulting from comparison of the values for sodium plus potassium per liter of total muscle water and for concentration of potassium per liter of cell water in the normal animals with the same values in the edematous animals. A more detailed analysis of these figures can be had from Figure 2, and from the following discussion of the tables. For the first series of edematous animals in Table II the average values are essentially the same as the complete average for the first series of normal animals in Table I, though there is more variation in these values among the edematous group. For values of concentration of potassium in cell water there are three higher than the highest normal and one $\left(K_{3}\right)$ so much lower than the lowest that there seems a possibility of technical error as mentioned above. For the second series of edematous animals, Table IV, these average values are 5 and 8 per cent higher than the same averages for the second series of normals, Table III. As before, there is also more variation than among the normal group but this second normal group itself shows much more variation than the earlier normals, and the average figure for sodium plus potassium concentration is $\mathbf{5}$ per cent lower, the potassium concentration 6 per cent lower than the corresponding figures in the first normal series. Were this last edematous series to be compared with the earlier normals then, it would hardly show any significant difference in average values. It is perhaps more reasonable to make the comparison with the group of normals which was dieted coincidentally and in which the procedure for analyses was the same. From this comparison it might be concluded that there is a tendency for slightly higher osmotic 


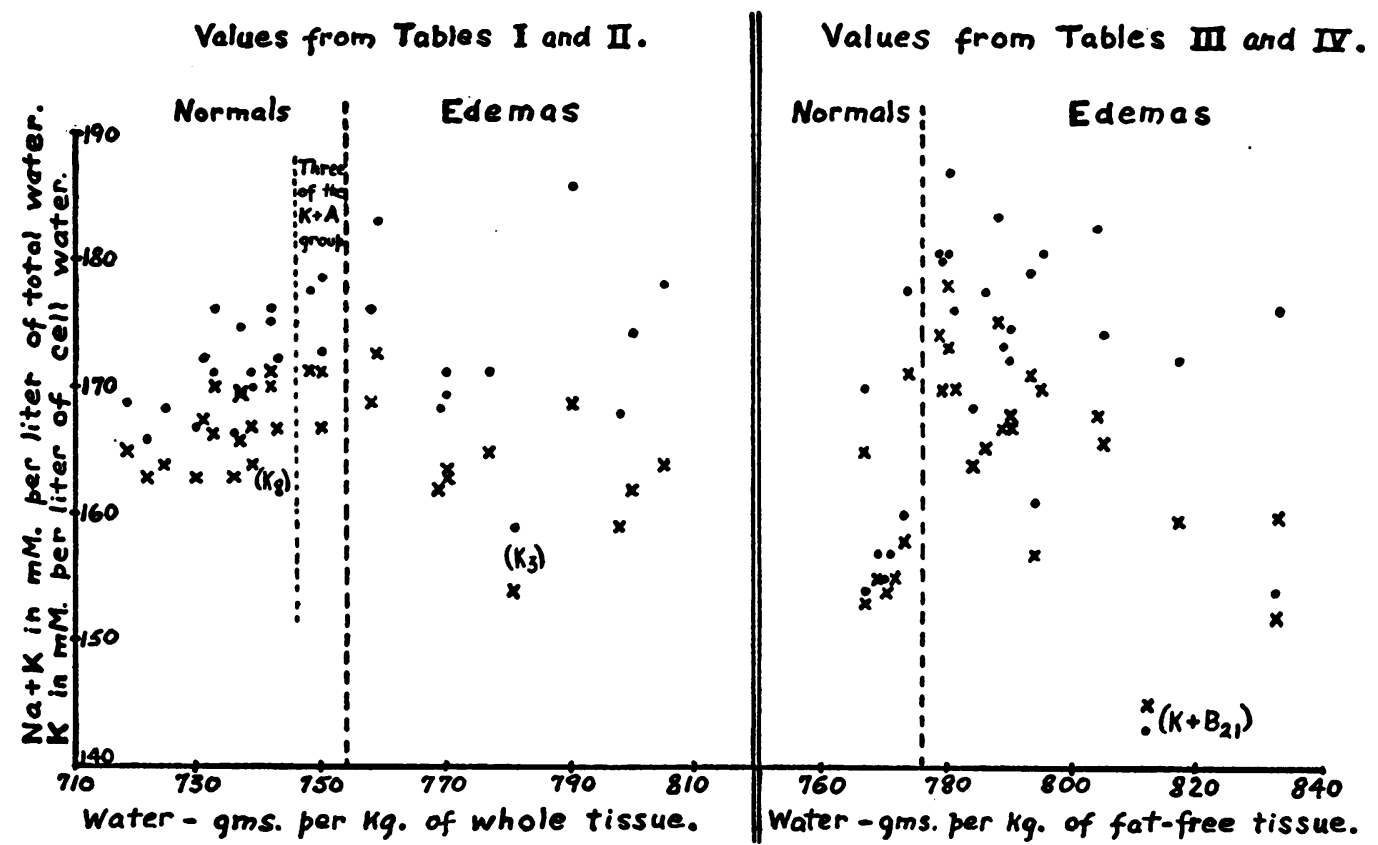

Fig. 2. The Concentration of Muscle Bases in Relation to the Water Content of the Muscle.

The crosses represent values for the concentration of $\mathrm{Na}+\mathrm{K}$ in total water, and the dots, values for the concentration of $K$ in calculated cell water.

concentrations in the total muscle water of edematous rats than in the muscle water of normal rats. This could be a reflection of a slightly higher than normal sodium concentration in the plasma of edematous rats, which might show its effect in the tissues as an increased sodium concentration in interstitial fluid, and, in consequence, by a shift of water out of the cells to satisfy osmotic equilibrium, an increased potassium concentration in the cell water. Darrow and Yannet $(29,30)$ have shown definitely that the shift of water between erythrocytes and plasma is such as to reestablish osmotic equilibrium when a change from the normal has occurred in the osmolal concentration of the plasma. As these authors and Peters (27, pages 144,145$)$ argue, the same is to be expected between other cells and the fluid surrounding them. Without serum sodium figures to establish a relationship between the muscle bases and the chief base of the serum, we cannot go beyond conjecture on this point. At any rate, the increased base concentration in these edematous rats is not out of physiologic range, and must theoretically be shared by both the intracellular and extracellular water. This would indicate that the figure used for sodium concentration in the interstitial fluid of normal animals should have been slightly lower than that of the edema fluids. There seems to be no correlation of this tendency to higher base concentration with the degree of edema.

\section{CONCLUSIONS}

Lack of vitamin $G$ is not significant for the occurrence of edema in young rats on a proteinpoor carrot diet. The addition to the diet of as small an amount as 0.05 gram daily of a biologically good protein causes some delay in the edema formation.

The ratio of albumin to globulin in normal rat serum is equal to 1 , as contrasted to approximately 2 in normal human serum. The loss of serum protein in rats with a nutritional edema is more at the expense of serum albumin than serum globulin, as in the human edema, so that the ratio of serum albumin to globulin becomes less than 1 .

The calculated values for amounts of extracellular water in muscle with declining serum protein values indicate that the retention of fluid in the muscle begins with the first loss of serum 
protein and progresses with increasing hypoproteinemia. This finding argues against the concept of a "critical level" of plasma proteins for the formation of edema fluid. The progressively greater accumulation of edema fluid in the muscle when the plasma protein drops below 4.5 per cent correlates with the gross findings in clinical edemas.

In general, the values of muscle sodium and potassium, and of muscle water in rats with a nutritional edema are such as to be accounted for by normal concentrations of sodium in extracellular water and potassium in intracellular water. An appreciable number of edematous animals did show a 5 to 8 per cent increased concentration for these two bases combined, but this is not out of physiologic range of osmolal changes. The theory that the accumulation of fluid in the tissues in conditions of hypoproteinemia is simply a result of ultrafiltration through the capillaries caused by the reduced plasma osmotic pressure is compatible with these determinations of the predominant bases in edematous rat muscles.

\section{BIBLIOGRAPHY}

1. Leiter, L., Experimental nephrotic edema. Arch. Int. Med., 1931, 48, 1.

2. Fahr, G., Kerkhof, A., and Giere, E., Salt as a factor in edema formation following plasmapheresis. Proc. Soc. Exper. Biol. and Med., 1931, 29, 335.

3. Weech, A. A., and Goettsch, E., The action of sodium chloride in edema produced experimentally in dogs. Am. J. Dis. Child. (Proc.), 1933, 46, 447.

4. Weech, A. A., and Ling, S. M., Nutritional edema. Observations on the relation of the serum proteins to the occurrence of edema and to the effect of certain inorganic salts. J. Clin. Invest., 1931, 10, 869.

5. Blum, L., Aubel, E., and Hausknecht, R., Le mécanisme de l'action du chlorure de sodium et du chlorure de potassium dans les néphrites hydropigènes. Compt. rend. Soc. de biol., 1921, 85, 123.

6. Kohman, E., The experimental production of edema as related to protein deficiency. Am. J. Physiol., 1920, 51, 378.

7. Maver, M. B., Nutritional edema and "War Dropsy." J. A. M. A., 1920, 74, 934.

8. Frisch, R. A., Mendel, L. B., and Peters, J. P., The production of edema and serum protein deficiency in white rats by low protein diets. J. Biol. Chem., 1929, 84, 167.
9. Bloomfield, A. L., The effect of carrot feeding on the serum protein concentration of the rat. J. Exper. Med., 1934, 59, 687.

10. Hastings, A. B., and Eichelberger, L., The exchange of salt and water between muscle and blood. J. Biol. Chem. (In press). (Reported: Proc. Am. Soc. Biol. Chem.; J. Biol. Chem., 1935, 109, xli.

11. Salit, P. W., A new triple acetate method for sodium determinations in biological materials. J. Biol. Chem., 1932, 96, 659.

12. Hoffman, W. S., The micro determination of fixed bases, calcium, and sulfates in urine. J. Biol. Chem., 1931, 93, 787.

13. Butler, A. M., and Tuthill, E., An application of the uranyl zinc acetate method for determination of sodium in biological material. J. Biol. Chem., 1931, 93, 171.

14. Barber, H. H., and Kolthoff, I. M., A specific reagent for the rapid gravimetric determination of sodium. J. Am. Chem. Soc., 1928, 50, 1625.

15. Mond, R., and Netter, H., Uber die Regulation des Natriums durch den Muskel. Arch. f. d. ges. Physiol., 1932, 230, 42.

16. Shohl, A. T., and Bennett, H. B., A micro method for the determination of potassium as iodoplatinate. J. Biol. Chem., 1928, 78, 643.

17. Howe, P. E., The use of sodium sulphate as the globulin precipitant in the determination of proteins in blood. J. Biol. Chem., 1921, 49, 93.

The determination of proteins in blood-A micro method. Ibid., 1921, 49, 109.

18. Koch, F. C., and McMeekin, T. L., A new direct nesslerization microkjeldahl method and a modification of the Nessler-Folin reagent for ammonia. J. Am. Chem. Soc., 1924, 46, 2066.

19. Loeb, R. F., Atchley, D. W., and Palmer, W. W., On the equilibrium condition between blood serum and serous cavity fluids. J. Gen. Physiol., 1922, 4, 591.

20. Hastings, A. B., Salvesen, H. A., Sendroy, J., Jr., and Van Slyke, D. D., Studies of gas and electrolyte equilibria in the blood. IX. The distribution of electrolytes between transudates and serum. J. Gen. Physiol., 1927, 8, 701.

21. Greene, C. H., Bollman, J. L., Keith, N. M., and Wakefield, E. G., The distribution of electrolytes between serum and transudates. J. Biol. Chem., 1931, 91, 203.

22. Harrison, H. E., Darrow, D. C., and Yannet, H., The total electrolyte content of animals and its probable relation to the distribution of body water. J. Biol. Chem., 1936, 113, 515.

23. Weech, A. A., Snelling, C. E., and Goettsch, E., The relation between plasma protein content, plasma specific gravity and edema in dogs maintained on a protein inadequate diet and in dogs rendered edematous by plasmapheresis. J. Clin. Invest., 1933, 12, 193. 
24. Gamble, J. L., Ross, G. S., and Tisdall, F. F., The metabolism of fixed base during fasting. J. Biol. Chem., 1923, 57, 633.

25. Lavietes, P. H., D'Esopo, L. M., and Harrison, H. E., The water and base balance of the body. J. Clin. Invest., 1935, 14, 251.

26. Lepore, M. J., Experimental edema produced by plasma protein depletion. Arch. Int. Med., 1932, $50,488$.

27. Peters, J. P., Body Water, the Exchange of Fluids in Man. Charles C. Thomas, 1935, Springfield, III.

28. Light, A. E., Smith, P. K., Smith, A. H., and Ander- son, W. E., Inorganic salts in nutrition. XI. Changes in composition of the whole animal induced by a diet poor in salts. J. Biol. Chem., 1934, 107, 689.

29. Darrow, D. C., and Yannet, H., The changes in the distribution of body water accompanying increase and decrease in extracellular electrolyte. J. Clin. Invest., 1935, 14, 266.

30. Yannet, H., Darrow, D. C., and Cary, M. K., The effect of changes in the concentration of plasma electrolytes on the concentration of electrolytes in the red blood cells of dogs, monkeys, and rabbits. J. Biol. Chem., 1936, 112, 477. 